\title{
Final year dental students' assessment of their profile, competencies and skills in a public university
}

\author{
Maria do Carmo Matias Freire ${ }^{1, *}$, Danilo Pereira da \\ Silva $^{2}$, Aline de Paula Ferreira Caetano ${ }^{3}$, Maria de \\ Fátima Nunes ${ }^{4}$
}

${ }^{1}$ Full Professor. School of Dentistry, Federal University of Goiás, Goiânia GO, Brazil.

2 DDS. School of Dentistry, Federal University of Goiás, Goiânia, GO, Brazil.

${ }^{3}$ MSc student. Dentistry Graduate Programme, School of Dentistry, Federal University of Goiás, Goiânia, GO, Brazil.

${ }^{4}$ Associate Professor. School of Dentistry, Federal University of Goiás, Goiânia, GO, Brazil.
Corresponding author: Maria do Carmo Matias Freire Faculdade de Odontologia da Universidade Federal de Goiás Av. Universitária, $s / n$, Setor Leste Universitário, Goiânia - GO, 74605-020, Brasil. Telefone/FAX: (62) 3209-6325 mcmfreire@yahoo.com.br ORCID: 0000-0001-6078-6728

Received: December 21, 2018 Accepted: April 27, 2019

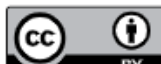

Aim: To investigate final-year dental students' assessment of their achievement of professional profile, competencies and skills as set out in the National Curriculum Guidelines (NCG) and its association with demographic characteristics. Methods: A cross-sectional study was carried out at the dental school of the Federal University of Goiás, Brazil. The study population ( $N=205$ ) was composed of all undergraduate students finishing their courses under the new curricula over a five-year period. They were asked to score their achievement of the professional profile, competencies and skills proposed by the NCG using a 3-point scale. Frequency distribution of the data was described and scores for competencies and skills were calculated. The total score was the sum of those obtained in each single item. For group comparisons regarding to the students' demographic characteristics, Mann-Whitney test was performed with statistical significance of $5 \%$. Results: The sample was composed by 204 final year students (response rate $=99.5 \%$ ). Only one student considered that she did not have the profile proposed in the NCG. $52 \%$ of them reported they had fully achieved the professional profile, while the remaining reported they had partially achieved it. High percentages of responses indicating partial or total achievement of general and specific competencies and skills were also found. The total score ranged from 36 to 72 (mean=60.2; SD= 7.68; median=62.0). Women reported higher levels of competencies and skills relating teamwork and the social context of the profession. Men reported higher levels of skills related to decision-making and activities aimed at disease diagnosis and interventions. Younger students, compared to older ones, had higher scores on five items of specific competencies and skills. Conclusion: Most of the students considered to have achieved the professional profile, competencies and skills proposed in the NCG, and their perceptions were associated with demographic characteristics (age and sex).

Keywords: Dental education. Students, Dental. Self-Assessment. Curriculum. Competency-based education. 


\section{Introduction}

Curriculum changes in undergraduate dental education have been conducted in diverse socioeconomic and cultural contexts in the last decades, placing greater emphasis on professional profiles and set of competencies, based on the needs and challenges of the 21 st century ${ }^{1-6}$.

In Brazil, following the 1996 Law on National Education Guidelines and Bases (LDB) ${ }^{7}$, National Curriculum Guidelines (NCG) for dental schools was introduced in 2002. In the Federal University of Goiás (UFG), Midwest of Brazil, curricular changes following the NCG were carried out in 2006. NCG defines the principles, foundations, conditions and procedures to be taken into consideration in the curricular organization of the National Institutions of the Higher Education System ${ }^{8}$. These guidelines were the basis for curricular changes that took place in undergraduate courses throughout the country, with the aim of training the graduating dentists "with a generalist, humanistic, critical and reflexive training to act at all levels of health care, based on technical and scientific rigor"8.

According to the official NCG document, the courses should also provide the students with the knowledge required to perform general and specific competencies and skills. Those of a general nature refer to health care, decision making, communication, leadership, management, and continuing education and management. Specific competencies and skills include 30 items to be taken into consideration during the training process ${ }^{8}$. Evaluation of the implementation of the curricular guidelines was recommended to identify any areas which needed improving. The courses should plan evaluation strategies that include all the sujects involved, and among them, the students.

More than a decade since the introduction of the new Brazilian NCG, studies on issues related to the implementation processes and their results in some faculties have been conducted $^{9-16}$. A few of them have investigated students' perceptions, but only part of the proposed competencies and skills were included ${ }^{9,15}$. Likewise, similar studies in developing and developed countries have focussed on specific components ${ }^{17,18}$. To our knowledge, no previous studies have investigated students' self-assessment at the end of the course regarding the whole set of profile, competencies and skills advocated by national curricula.

Students' self-perception can be an important indicator of self-confidence in trainning and preparedness for coping with professional life, in addition to indicating if the pedagogical projects are in fact contributing to the fulfillment of the guidelines. Thus, studies focusing on this dimension and on the students' perspectives are in line with the new trends in the field of health education assessment ${ }^{19}$. Previous studies have shown that males and females assess their own competencies acquired in dental education in different ways ${ }^{17,18}$. We have, therefore, aimed to explore sex and also age differences in our sample of Brazilian students.

The objective of the present study is to investigate final-year dental students' assessment of the achievement of their professional profile, competencies and skills as set out in the National Curriculum Guidelines (NCG) and its association with demographic characteristics. 


\section{Materials and Methods}

A cross-sectional study was conducted at the Faculty of Dentistry of the UFG, which is a public institution located in the Midwest of Brazil. The project was approved by the UFG Research Ethics Committee (protocol nº 085/06). The study population consisted of all undergraduate students finishing their courses under the new curricula over a five-year period (2010 to 2014). The course is organised in ten semesters (totalling five years). Elligible participants ( $N=205)$ were the Brazilian students attending the last semester, who had not initiated a dental course in another faculty. All those who agreed to participate in the study signed an informed consent term.

Data were collected through a self-administered anonymous questionnaire, based on a similar study conducted in Peru ${ }^{17}$. The instrument included variables related to the demographic characteristics of the students (sex and age), and 37 items regarding the professional profile, the six general competencies and skills (Table 1) and the 30 specific competencies and skills (Figure 1) established in the $\mathrm{NCG}^{8}$. The students were asked to select a response from a scale provided that corresponded to their perception in relation to each of the items. For this, a 3-point scale was used, with scores from 0 to 2 . The question about the professional profile had the following response categories: 0- "Not achieved (I do not have this profile)"; 1- "Partially achieved (I have only part of this profile)"; and 2- "Totally achieved (I have exactly this profile)". For the questions about the competencies and skills the following categories were presented: 0- "None"; 1- "Partially"; and 2- "Totally".

Data collection was carried out in the classrooms during the last academic month of each year (second semester), by four previously trained undergraduate students enrolled in other academic years. The absence of members of university staff (lecturers and technicians) at this stage had the purpose of not influencing the students' responses.

The Statistical Package for Social Sciences (SPSS for Windows, version 16.0) software was used for data analysis. The absolute (n) and relative frequencies (\%) of the studied variables were initially calculated. The score of each item was obtained by the estimation of the means, standard deviation (SD) and medians of the scores. The total score was the sum of the scores obtained on each single item, including the

Table 1. Dental students' self-perceptions of professional profile and general competencies/skills. (N=204). Goiânia, 2010-2014.

\begin{tabular}{lcccc}
\hline $\begin{array}{l}\text { Items in the National } \\
\text { Curriculum Guidelines }\end{array}$ & $\begin{array}{c}\text { Not } \\
\text { achieved-0 } \\
\mathbf{n}(\%)\end{array}$ & $\begin{array}{c}\text { Partially } \\
\text { achieved-1 } \\
\mathbf{n}(\%)\end{array}$ & $\begin{array}{c}\text { Totally } \\
\text { achieved-2 } \\
\mathbf{n}(\%)\end{array}$ & $\begin{array}{c}\text { No response } \\
\mathbf{n}(\%)\end{array}$ \\
\hline Professional profile & $1(0.5)$ & $95(46.6)$ & $106(52.0)$ & $2(0,9)$ \\
\hline General competencies and skills & & & & \\
\hline Health care & $1(0.5)$ & $43(21.1)$ & $160(78.4)$ & - \\
\hline Communication & $2(1.0)$ & $43(21.1)$ & $159(77.9)$ & - \\
\hline Permanent education & $1(0.5)$ & $78(38.2)$ & $124(60.8)$ & $1(0.5)$ \\
\hline Leadership & $4(2.0)$ & $86(42.2)$ & $114(55.9)$ & - \\
\hline Decision making & $1(0.5)$ & $99(48.5)$ & $104(51.0)$ & - \\
\hline Administration and management & $28(13.7)$ & $128(62.7)$ & $48(23.5)$ & - \\
\hline
\end{tabular}




\begin{tabular}{|c|c|}
\hline Item & NCG specific competencies and skills \\
\hline 1 & Respecting the ethical and legal principles inherent to professional practice. \\
\hline 2 & $\begin{array}{l}\text { Acting at all levels of health care, integrating in programs of promotion, maintenance, prevention, } \\
\text { protection and recovery of health, sensitized and committed to the human being, respecting and } \\
\text { valuing it. }\end{array}$ \\
\hline 3 & $\begin{array}{l}\text { Acting multiprofessional, interdisciplinary and transdisciplinarily with extreme productivity in health } \\
\text { promotion based on scientific conviction, citizenship and ethics. }\end{array}$ \\
\hline 4 & $\begin{array}{c}\text { Recognize health as a right and adequate living conditions and act in a way to guarantee the } \\
\text { integrality of care, understood as an articulated and continuous set of preventive and curative } \\
\text { actions and services, individual and collective, required for each case at all levels of complexity of } \\
\text { the system. }\end{array}$ \\
\hline 5 & $\begin{array}{l}\text { Exercise their profession in an articulated way, to the social context, understanding it as a form of } \\
\text { participation and social contribution. }\end{array}$ \\
\hline 6 & Know methods/techniques of investigation and elaboration of academic and scientific works. \\
\hline 7 & Develop individual and collective dental care. \\
\hline 8 & $\begin{array}{l}\text { Identify in patients and in population groups the maxillofacial diseases and disorders and to } \\
\text { perform adequate procedures for their investigation, prevention, treatment and control. }\end{array}$ \\
\hline 9 & Fulfilling basic investigations and operative procedures. \\
\hline 10 & Promoting oral health and preventing diseases and oral disorders. \\
\hline 11 & $\begin{array}{c}\text { Communicate and work effectively with patients, health workers and other relevant individuals, } \\
\text { groups and organizations. }\end{array}$ \\
\hline 12 & Obtain and efficiently record reliable information and evaluate it objectively. \\
\hline 13 & $\begin{array}{l}\text { Apply knowledge and understanding of other aspects of health care in the search for more adequate } \\
\text { solutions to clinical problems in the interests of both the individual and the community. }\end{array}$ \\
\hline 14 & Analyze and interpret the results of relevant experimental, epidemiological and clinical research. \\
\hline 15 & Organize, handle and evaluate health care resources effectively and efficiently. \\
\hline 16 & $\begin{array}{l}\text { Apply knowledge of oral health, diseases and related topics in the best interest of the individual and } \\
\text { the community. }\end{array}$ \\
\hline 17 & $\begin{array}{l}\text { Participate in continuing education concerning oral health and diseases as a component of } \\
\text { professional obligation and maintain a critical spirit, but open to new information. }\end{array}$ \\
\hline 18 & $\begin{array}{c}\text { Participate in scientific research on diseases and oral health and be prepared to apply research } \\
\text { results to health care. }\end{array}$ \\
\hline 19 & $\begin{array}{l}\begin{array}{l}\text { Seek to improve perception and provide solutions to oral health problems and related areas and } \\
\text { global community needs. }\end{array}\end{array}$ \\
\hline 20 & $\begin{array}{c}\text { Maintain recognized standard of professional ethics and conduct, and apply it in all aspects of } \\
\text { professional life. }\end{array}$ \\
\hline 21 & Be aware of the rules of oral health workers in society and have personal responsibility for such rules. \\
\hline 22 & Recognize your limitations and be adaptable and flexible in the face of changing circumstances. \\
\hline 23 & Collecting, observing and interpreting data for the construction of the diagnosis. \\
\hline 24 & To identify prevalent oral and maxillofacial affections. \\
\hline 25 & Proposing and implementing adequate treatment plans \\
\hline 26 & Performing oral health preservation. \\
\hline 27 & Communicate with patients, health professionals and the community. \\
\hline 28 & Working in interdisciplinary teams and acting as a health promotion agent \\
\hline 29 & Plan and administer community health services. \\
\hline 30 & $\begin{array}{l}\text { Accompany and incorporate technological innovations (informatics, new materials, biotechnology) } \\
\text { in the exercise of the profession. }\end{array}$ \\
\hline
\end{tabular}

Figure 1. Specific competencies and skills proposed in the National Curriculum Guidelines (NCG) for dental courses in Brazil, 2002. 
36 competencies and skills, and could range from 0 to 72 . Higher scores indicate greater competencies and skills. We have tested the normality of the scores' distribution using Kolmogorov-Smirnoff test and all items presented asymmetrical distribution. To investigate associations between the scores of competencies and skills and the students' sex and age, Mann-Whitney test was performed, with statistical significance of $5 \%$.

\section{Results}

Of the 205 graduates invited, only one did not agree to participate ( $N=204$; response rate $=99.5 \%$ ). The years of completion of the course and respective number of students were: $2010(n=53), 2011(n=53), 2012(n=52)$ and $2014(n=46)$. The sample was predominantly female (66.2\%). Age ranged from 21 to 37 years (mean= 23.3; $\mathrm{SD}=2.0$ ). For the purpose of the statistical analysis, this variable was categorized in two groups: 21 to 22 years (36.3\%) and 23 to 37 years (63.7\%).

Frequency distribution of the students' perception of their professional profile and general competencies are in Table 1. Only one student reported she did not have the professional profile proposed in the NCG. For more than half (52\%) the profile was fully achieved. A high proportion of students also reported partial or total achievement of general competencies and skills. The item with the highest percentage of total achievement was "Health care" (78.4\%), while "Administration and management" had the lowest percentage (23.5\%).

Results of the association between scores of self-perceived professional profile and general competencies/skills and demographic characteristics of the respondents are in Table 2. There were no significant sex and age differences in the

Table 2. Associations between scores of self-perceived professional profile and general competencies/ skills and demographic variables. Goiânia, Brazil, 2010-2014.

\begin{tabular}{|c|c|c|c|c|c|c|c|}
\hline & \multirow[b]{2}{*}{$\begin{array}{l}\text { Total sample } \\
\text { Mean (sd) } \\
\text { Median }\end{array}$} & \multicolumn{3}{|c|}{ Sex } & \multicolumn{3}{|c|}{ Age (years) } \\
\hline & & $\begin{array}{c}\text { Male } \\
\text { Mean (SD) } \\
\text { Median }\end{array}$ & $\begin{array}{l}\text { Female } \\
\text { Mean (SD) } \\
\text { Median }\end{array}$ & p-value $e^{\star \star \star}$ & $\begin{array}{c}21-22 \\
\text { Mean (SD) } \\
\text { Median }\end{array}$ & $\begin{array}{c}23-37 \\
\text { Mean (SD) } \\
\text { Median }\end{array}$ & p-value \\
\hline $\begin{array}{l}\text { Professional } \\
\text { profile }^{*}\end{array}$ & $\begin{array}{l}2.52(0.51) \\
2.00\end{array}$ & $\begin{array}{l}2.51(0.50) \\
3.00\end{array}$ & $\begin{array}{c}2.53(0.52) \\
3.00\end{array}$ & 0.767 & $\begin{array}{c}2.57(0.50) \\
3.00\end{array}$ & $\begin{array}{c}2.49(0.52) \\
2.5\end{array}$ & 0.333 \\
\hline \multicolumn{8}{|l|}{$\begin{array}{l}\text { General } \\
\text { competencies } \\
\text { and skills }\end{array}$} \\
\hline Health care & $\begin{array}{l}1.78(0.43) \\
2.00\end{array}$ & $\begin{array}{l}1.77(0.43) \\
2.00\end{array}$ & $\begin{array}{c}1.81(0.44) \\
2.00\end{array}$ & 0.535 & $\begin{array}{c}1.82(0.38) \\
2.00\end{array}$ & $\begin{array}{c}1.76(0.45) \\
2.00\end{array}$ & 0.286 \\
\hline Communication & $\begin{array}{c}1.77(0.44) \\
2.00\end{array}$ & $\begin{array}{c}1.69(0.50) \\
2.00\end{array}$ & $\begin{array}{c}1.81(0.42) \\
2.00\end{array}$ & 0.088 & $\begin{array}{c}1.86(0.38) \\
2.00\end{array}$ & $\begin{array}{c}1.71(0.47) \\
2.00\end{array}$ & 0.012 \\
\hline $\begin{array}{l}\text { Permanent } \\
\text { education }\end{array}$ & $\begin{array}{c}1.61(0.50) \\
2.00\end{array}$ & $\begin{array}{c}1.63(0.49) \\
2.00\end{array}$ & $\begin{array}{c}1.59(0.51) \\
2.00\end{array}$ & 0.630 & $\begin{array}{c}1.61(0.49) \\
2.00\end{array}$ & $\begin{array}{c}1.60(0.51) \\
2.00\end{array}$ & 0.986 \\
\hline Leadership & $\begin{array}{c}1.54(0.54) \\
2.00\end{array}$ & $\begin{array}{c}1.55(0.53) \\
2.00\end{array}$ & $\begin{array}{l}1.53(0.54) \\
2.00\end{array}$ & 0.862 & $\begin{array}{c}1.59(0.52) \\
2.00\end{array}$ & $\begin{array}{c}1.51(0.55) \\
2.00\end{array}$ & 0.273 \\
\hline Decision making & $\begin{array}{c}1.50(0.51) \\
2.00\end{array}$ & $\begin{array}{c}1.64(0.48) \\
1.00\end{array}$ & $\begin{array}{c}1.44(0.51) \\
2.00\end{array}$ & 0.008 & $\begin{array}{c}1.50(0.53) \\
2.00\end{array}$ & $\begin{array}{c}1.51(0.50) \\
2.00\end{array}$ & 0.991 \\
\hline $\begin{array}{l}\text { Administration } \\
\text { and management }\end{array}$ & $\begin{array}{c}1.10(0.60) \\
1.00\end{array}$ & $\begin{array}{c}1.13(0.62) \\
1.00\end{array}$ & $\begin{array}{c}1.07(0.59) \\
1.00\end{array}$ & 0.414 & $\begin{array}{c}1.04(0.58) \\
1.00\end{array}$ & $\begin{array}{c}1.13(0.62) \\
1.00\end{array}$ & 0.293 \\
\hline
\end{tabular}

*Two non-responses ${ }^{* \star}$ One non-response ${ }^{* \star *}$ Mann-Whitney test 
responses regarding the professional profile ( $p>0.05)$. Male students had higher scores in the item "Decision making" than female ones $(p<0.01)$. The younger group had a higher score in the item "Communication", compared to those aged 23 years and above $(p<0.05)$.

Regarding specific competencies and skills (Table 3), the vast majority of the respondents considered having acquired them either partially or totally. In 27 of the 30 items the answer totally predominated. The itens with the highest frequencies of total achievement were "Performing oral health preservation - Item 26" (90.7\%) and

Table 3. Self-perception of specific competencies and skills. Goiânia, Brazil, 2010-2014.

\begin{tabular}{|c|c|c|c|c|}
\hline $\begin{array}{l}\text { Specific competencies } \\
\text { and skills }{ }^{\star}\end{array}$ & $\begin{array}{l}\text { None-0 } \\
\mathrm{n}(\%)\end{array}$ & $\begin{array}{l}\text { Partially-1 } \\
\text { n (\%) }\end{array}$ & $\begin{array}{l}\text { Totally-2 } \\
\mathrm{n}(\%)\end{array}$ & $\begin{array}{c}\text { No response } \\
\mathrm{n}(\%)\end{array}$ \\
\hline 1 & - & $8(3.9)$ & $182(89.2)$ & $14(6.9)$ \\
\hline 2 & $2(1.0)$ & 57 (27.9) & $143(70.1)$ & $2(1.0)$ \\
\hline 3 & - & 78 (38.2) & $126(61.8)$ & - \\
\hline 4 & - & $34(16.7)$ & $169(82.8)$ & $1(0.5)$ \\
\hline 5 & - & $51(25.0)$ & $153(75.0)$ & - \\
\hline 6 & $4(2.0)$ & $95(46.6)$ & $105(51.5)$ & - \\
\hline 7 & - & 37 (18.1) & $164(80.4)$ & $3(1.5)$ \\
\hline 8 & $3(1.5)$ & $106(52.0)$ & $93(45.6)$ & $2(1.0)$ \\
\hline 9 & - & $40(19.6)$ & $161(78.9)$ & $3(1.5)$ \\
\hline 10 & - & $34(16.7)$ & $166(81.4)$ & $4(2.0)$ \\
\hline 11 & - & $43(21.1)$ & $161(78.9)$ & - \\
\hline 12 & $1(0.5)$ & $64(31.4)$ & $137(67.2)$ & $2(1.0)$ \\
\hline 13 & $3(1.5)$ & 75 (36.8) & $124(60.8)$ & $2(1.0)$ \\
\hline 14 & $5(2.5)$ & $120(58.8)$ & 79 (38.7) & - \\
\hline 15 & $8(3.9)$ & $97(47.5)$ & $98(48.0)$ & $1(0.5)$ \\
\hline 16 & $1(0.5)$ & $57(27.9)$ & $142(69.6)$ & $4(2.0)$ \\
\hline 17 & $1(0.5)$ & $61(29.9)$ & $142(69.6)$ & - \\
\hline 18 & $5(2.5)$ & $89(43.6)$ & $109(53.4)$ & $1(0.5)$ \\
\hline 19 & $2(1.0)$ & $82(40.2)$ & $120(58.8)$ & - \\
\hline 20 & - & $29(14.2)$ & $174(85.3)$ & $1(0.5)$ \\
\hline 21 & $3(1.5)$ & $54(26.5)$ & $146(71.6)$ & $1(0.5)$ \\
\hline 22 & $2(1.0)$ & $32(15.7)$ & $170(83.3)$ & - \\
\hline 23 & - & $49(24.0)$ & $153(75.0)$ & $2(1.0)$ \\
\hline 24 & $2(1.0)$ & $88(43.1)$ & $114(55.9)$ & - \\
\hline 25 & - & $70(34.3)$ & $134(65.7)$ & - \\
\hline 26 & - & $17(8.3)$ & $185(90.7)$ & $2(1.0)$ \\
\hline 27 & - & $24(11.8)$ & $179(87.7)$ & $1(0.5)$ \\
\hline 28 & $3(1.5)$ & $41(20.1)$ & $155(76.0)$ & $5(2.5)$ \\
\hline 29 & $14(6.9)$ & $100(49.0)$ & 89 (43.6) & $1(0.5)$ \\
\hline 30 & $4(2.0)$ & $73(35.8)$ & $127(62.3)$ & - \\
\hline
\end{tabular}

Numbered according to Figure 1. 
"Respecting the ethical and legal principles inherent to professional practice - Item 1" (89.2\%). "Analyze and interpret the results of relevant experimental, epidemiological and clinical research - Item $14^{\prime \prime}$ had the lowest frequency (38.7\%). Competence to "Plan and administer community health services - Item 29" had the highest percentage of students who reported no achievement (6.9\%).

There were differences in the scores of specific competencies and skills in relation to sex and age (Table 4). Female students, compared to males, had higher scores in three itens: "Exercise their profession in an articulated way, to the social context, understanding it as a form of participation and social contribution - Item $5^{\prime \prime}(p<0.01)$, "Seek to improve perception and provide solutions to oral health problems and related areas and global community needs - Item 19" ( $p<0.05$ ), and "Working in interdisciplinary teams and acting as a health promotion agent - Item $28^{\prime \prime}(p<0.05)$. Males had higher scores in the item "Identify in patients and in population groups the maxillofacial diseases and disorders and to perform adequate procedures for their investigation, prevention, treatment and control - Item $8^{\prime \prime}(p<0.01)$.

Younger students, when compared to older ones, presented higher scores on five items (Table 4): "Identify in patients and in population groups the maxillofacial diseases and disorders and to perform adequate procedures for their investigation, prevention, treatment and control - Item 8 " ( $p<0.01)$, "Fulfilling basic investigations and operative procedures - Item 9 " ( $P<0.05)$, "Seek to improve perception and provide solutions to oral health problems and related areas and global community needs - Item 19" ( $p<0.05)$, "Proposing and implementing adequate treatment plans - Item $25^{\prime \prime}(\mathrm{p}<0.05)$, and "Performing oral health preservation - Item $26^{\prime \prime}(p<0.01)$.

The total score, which included all general and specific competencies and skills, ranged from 36 to 72, with mean=60.2 (SD=7.68) and median= 62.0 (Data not in table). Students who have not answered to all questions ( $N=43 ; 21.1 \%)$ were excluded from this calculation. There were no sex and age significant differences in the responses.

\section{Discussion}

The present study, based on the self-perception of final year students, showed that the great majority perceived they have acquired the professional profile and the competencies/skills proposed in the $\mathrm{NCG}^{8}$. This finding has important implications not only for the course studied, since this is the first research that includes the profile and all competencies and skills proposed in the current curricular guidelines for dental schools in Brazil in the beginning of the 21st century.

The results are encouraging, as they have revealed a very positive perception of the students. Although not directly questioned if they were prepared for professional practice, the set of answers altogether indicated that they were. These findings are not sufficient, however, to evaluate the results of the curricular changes that were implemented in the year 2006. For this purpose, evaluation studies encompassing other aspects and subjects involved are essential, such as the evaluation of the students' level of knowledge, technical skills and preparedness to practice, as well as the faculty staff perceptions of the process and the results of the curricular change. 
Table 4. Associations between scores of self-perceived specific competencies/skills and demographic variables. Goiânia, Brazil, 2010-2014.

\begin{tabular}{|c|c|c|c|c|c|c|c|}
\hline \multirow[b]{2}{*}{$\begin{array}{l}\text { Specific } \\
\text { competencies/ } \\
\text { skills* }^{\star}\end{array}$} & \multirow[b]{2}{*}{$\begin{array}{c}\text { Total sample } \\
\text { Mean (SD) } \\
\text { Median }\end{array}$} & \multicolumn{3}{|c|}{ Sex } & \multicolumn{3}{|c|}{ Age (years) } \\
\hline & & $\begin{array}{c}\text { Male } \\
\text { Mean (SD) } \\
\text { Median }\end{array}$ & $\begin{array}{c}\text { Female } \\
\text { Mean (SD) } \\
\text { Median }\end{array}$ & p-value $e^{\star \star}$ & $\begin{array}{c}21-22 \\
\text { Mean (SD) } \\
\text { Median }\end{array}$ & $\begin{array}{c}23-37 \\
\text { Mean (SD) } \\
\text { Median }\end{array}$ & $p$-value ${ }^{\star \star}$ \\
\hline 1 & $\begin{array}{c}1.96(0.20) \\
2.00\end{array}$ & $\begin{array}{c}1.95(0.22) \\
2.00\end{array}$ & $\begin{array}{c}1.95(0.22) \\
2.00\end{array}$ & 0.790 & $\begin{array}{c}1.95(0.22) \\
2.00\end{array}$ & $\begin{array}{c}1.95(0.22) \\
2.00\end{array}$ & 0.994 \\
\hline 26 & $\begin{array}{c}1.92(0.28) \\
2.00\end{array}$ & $\begin{array}{c}1.90(0.30) \\
2.00\end{array}$ & $\begin{array}{c}1.94(0.24) \\
2.00\end{array}$ & 0.242 & $\begin{array}{c}1.98(0.13) \\
2.00\end{array}$ & $\begin{array}{c}1.89(0.31) \\
2.00\end{array}$ & 0.006 \\
\hline 27 & $\begin{array}{c}1.88(0.32) \\
2.00\end{array}$ & $\begin{array}{c}1.88(0.33) \\
2.00\end{array}$ & $\begin{array}{c}1.89(0.31) \\
2.00\end{array}$ & 0.399 & $\begin{array}{c}1.89(0.32) \\
2.00\end{array}$ & $\begin{array}{c}1.89(0.31) \\
2.00\end{array}$ & 0.736 \\
\hline 20 & $\begin{array}{c}1.86(0.35) \\
2.00 \\
\end{array}$ & $\begin{array}{c}1.90(0.30) \\
2.00 \\
\end{array}$ & $\begin{array}{c}1.83(0.38) \\
2.00 \\
\end{array}$ & 0.717 & $\begin{array}{c}1.92(0.28) \\
2.00 \\
\end{array}$ & $\begin{array}{c}1.81(0.39) \\
2.00 \\
\end{array}$ & 0.057 \\
\hline 4 & $\begin{array}{c}1.83(0.37) \\
2.00\end{array}$ & $\begin{array}{c}1.85(0.36) \\
2.00\end{array}$ & $\begin{array}{c}1.86(0.34) \\
2.00\end{array}$ & 0.877 & $\begin{array}{c}1.85(0.36) \\
2.00\end{array}$ & $\begin{array}{c}1.86(0.35) \\
2.00\end{array}$ & 0.763 \\
\hline 10 & $\begin{array}{c}1.83(0.38) \\
2.00 \\
\end{array}$ & $\begin{array}{c}1.78(0.42) \\
2.00 \\
\end{array}$ & $\begin{array}{c}1.85(0.35) \\
2.00 \\
\end{array}$ & 0.333 & $\begin{array}{c}1.89(0.32) \\
2.00 \\
\end{array}$ & $\begin{array}{c}1.79(0.41) \\
2.00 \\
\end{array}$ & 0.316 \\
\hline 7 & $\begin{array}{c}1.82(0.39) \\
2.00\end{array}$ & $\begin{array}{c}1.81(0.39) \\
2.00\end{array}$ & $\begin{array}{c}1.84(0.36) \\
2.00\end{array}$ & 0.909 & $\begin{array}{c}1.84(0.37) \\
2.00\end{array}$ & $\begin{array}{c}1.83(0.38) \\
2.00\end{array}$ & 0.832 \\
\hline 22 & $\begin{array}{c}1.82(0.41) \\
2.00 \\
\end{array}$ & $\begin{array}{c}1.80(0.48) \\
2.00 \\
\end{array}$ & $\begin{array}{c}1.81(0.40) \\
2.00 \\
\end{array}$ & 0.777 & $\begin{array}{c}1.85(0.40) \\
2.00 \\
\end{array}$ & $\begin{array}{c}1.77(0.45) \\
2.00 \\
\end{array}$ & 0.098 \\
\hline 9 & $\begin{array}{c}1.80(0.40) \\
2.00\end{array}$ & $\begin{array}{c}1.76(0.43) \\
2.00\end{array}$ & $\begin{array}{c}1.84(0.43) \\
2.00\end{array}$ & 0.585 & $\begin{array}{c}1.89(0.32) \\
2.00\end{array}$ & $\begin{array}{c}1.77(0.42) \\
2.00\end{array}$ & 0.036 \\
\hline 11 & $\begin{array}{c}1.79(0.41) \\
2.00 \\
\end{array}$ & $\begin{array}{c}1.78(0.42) \\
2.00\end{array}$ & $\begin{array}{c}1.82(0.39) \\
2.00 \\
\end{array}$ & 0.598 & $\begin{array}{c}1.82(0.38) \\
2.00 \\
\end{array}$ & $\begin{array}{c}1.79(0.41) \\
2.00\end{array}$ & 0.355 \\
\hline 23 & $\begin{array}{c}1.76(0.43) \\
2.00 \\
\end{array}$ & $\begin{array}{c}1.76(0.43) \\
2.00 \\
\end{array}$ & $\begin{array}{c}1.76(0.43) \\
2.00 \\
\end{array}$ & 0.864 & $\begin{array}{c}1.79(0.41) \\
2.00 \\
\end{array}$ & $\begin{array}{c}1.74(0.44) \\
2.00 \\
\end{array}$ & 0.109 \\
\hline 28 & $\begin{array}{c}1.76(0.46) \\
2.00 \\
\end{array}$ & $\begin{array}{c}1.68(0.51) \\
2.00\end{array}$ & $\begin{array}{c}1.80(0.45) \\
2.00\end{array}$ & 0.014 & $\begin{array}{c}1.76(0.47) \\
2.00\end{array}$ & $\begin{array}{c}1.75(0.48) \\
2.00\end{array}$ & 0.549 \\
\hline 5 & $\begin{array}{c}1.75(0.43) \\
2.00 \\
\end{array}$ & $\begin{array}{c}1.63(0.49) \\
2.00 \\
\end{array}$ & $\begin{array}{c}1.83(0.38) \\
2.00 \\
\end{array}$ & 0.008 & $\begin{array}{c}1.77(0.42) \\
2.00 \\
\end{array}$ & $\begin{array}{c}1.74(0.44) \\
2.00 \\
\end{array}$ & 0.867 \\
\hline 16 & $\begin{array}{c}1.71(0.47) \\
2.00 \\
\end{array}$ & $\begin{array}{c}1.69(0.50) \\
2.00\end{array}$ & $\begin{array}{c}1.79(0.41) \\
2.00\end{array}$ & 0.478 & $\begin{array}{c}1.81(0.40) \\
2.00\end{array}$ & $\begin{array}{c}1.72(0.47) \\
2.00\end{array}$ & 0.044 \\
\hline 2 & $\begin{array}{c}1.70(0.48) \\
2.00 \\
\end{array}$ & $\begin{array}{c}1.64(0.52) \\
2.00 \\
\end{array}$ & $\begin{array}{c}1.72(0.45) \\
2.00 \\
\end{array}$ & 0.298 & $\begin{array}{c}1.69(0.50) \\
2.00 \\
\end{array}$ & $\begin{array}{c}1.69(0.46) \\
2.00 \\
\end{array}$ & 0.883 \\
\hline 21 & $\begin{array}{c}1.70(0.49) \\
2.00\end{array}$ & $\begin{array}{c}1.66(0.54) \\
2.00\end{array}$ & $\begin{array}{c}1.74(0.44) \\
2.00\end{array}$ & 0.348 & $\begin{array}{c}1.79(0.41) \\
2.00\end{array}$ & $\begin{array}{c}1.66(0.52) \\
2.00\end{array}$ & 0.065 \\
\hline 17 & $\begin{array}{c}1.69(0.47) \\
2.00\end{array}$ & $\begin{array}{c}1.73(0.45) \\
2.00\end{array}$ & $\begin{array}{c}1.63(0.51) \\
2.00\end{array}$ & 0.508 & $\begin{array}{c}1.69(0.46) \\
2.00\end{array}$ & $\begin{array}{c}1.65(0.50) \\
2.00\end{array}$ & 0.850 \\
\hline 12 & $\begin{array}{c}1.67(0.48) \\
2.00\end{array}$ & $\begin{array}{c}1.66(0.48) \\
2.00\end{array}$ & $\begin{array}{c}1.68(0.49) \\
2.00\end{array}$ & 0.997 & $\begin{array}{c}1.77(0.46) \\
2.00\end{array}$ & $\begin{array}{c}1.61(0.49) \\
2.00\end{array}$ & 0.101 \\
\hline 25 & $\begin{array}{c}1.66(0.48) \\
2.00\end{array}$ & $\begin{array}{c}1.73(0.45) \\
2.00\end{array}$ & $\begin{array}{c}1.67(0.47) \\
2.00\end{array}$ & 0.146 & $\begin{array}{c}1.73(0.45) \\
2.00\end{array}$ & $\begin{array}{c}1.67(0.47) \\
2.00\end{array}$ & 0.024 \\
\hline 3 & $\begin{array}{c}1.62(0.49) \\
2.00\end{array}$ & $\begin{array}{c}1.63(0.49) \\
2.00\end{array}$ & $\begin{array}{c}1.63(0.48) \\
2.00\end{array}$ & 0.623 & $\begin{array}{c}1.60(0.50) \\
2.00\end{array}$ & $\begin{array}{c}1.65(0.48) \\
2.00\end{array}$ & 0.610 \\
\hline 13 & $\begin{array}{c}1.60(0.52) \\
2.00\end{array}$ & $\begin{array}{c}1.61(0.53) \\
2.00\end{array}$ & $\begin{array}{c}1.62(0.51) \\
2.00\end{array}$ & 0.846 & $\begin{array}{c}1.66(0.51) \\
2.00\end{array}$ & $\begin{array}{c}1.59(0.51) \\
2.00\end{array}$ & 0.807 \\
\hline 30 & $\begin{array}{c}1.60(0.53) \\
2.00\end{array}$ & $\begin{array}{c}1.66(0.54) \\
2.00 \\
\end{array}$ & $\begin{array}{c}1.61(0.51) \\
2.00 \\
\end{array}$ & 0.155 & $\begin{array}{c}1.73(0.45) \\
2.00 \\
\end{array}$ & $\begin{array}{c}1.57(0.56) \\
2.00 \\
\end{array}$ & 0.136 \\
\hline 19 & $\begin{array}{c}1.58(0.52) \\
2.00\end{array}$ & $\begin{array}{c}1.47(0.54) \\
2.00\end{array}$ & $\begin{array}{c}1.63(0.51) \\
1.00\end{array}$ & 0.047 & $\begin{array}{c}1.73(0.45) \\
2.00\end{array}$ & $\begin{array}{c}1.48(0.54) \\
1.50\end{array}$ & 0.011 \\
\hline
\end{tabular}




\begin{tabular}{|c|c|c|c|c|c|c|c|}
\hline 24 & $\begin{array}{c}1.55(0.52) \\
2.00\end{array}$ & $\begin{array}{c}1.61(0.56) \\
2.00\end{array}$ & $\begin{array}{c}1.52(0.50) \\
2.00\end{array}$ & 0.086 & $\begin{array}{c}1.61(0.49) \\
2.00\end{array}$ & $\begin{array}{c}1.52(0.54) \\
2.00\end{array}$ & 0.085 \\
\hline 18 & $\begin{array}{c}1.51(0.55) \\
2.00\end{array}$ & $\begin{array}{c}1.51(0.60) \\
2.00\end{array}$ & $\begin{array}{c}1.51(0.52) \\
2.00 \\
\end{array}$ & 0.703 & $\begin{array}{c}1.65(0.48) \\
2.00\end{array}$ & $\begin{array}{c}1.43(0.57) \\
1.00\end{array}$ & 0.061 \\
\hline 6 & $\begin{array}{c}1.50(0.54) \\
2.00\end{array}$ & $\begin{array}{c}1.42(0.56) \\
1.00\end{array}$ & $\begin{array}{c}1.55(0.52) \\
2.00\end{array}$ & 0.598 & $\begin{array}{c}1.56(0.50) \\
2.00\end{array}$ & $\begin{array}{c}1.47(0.56) \\
1.50\end{array}$ & 0.546 \\
\hline 8 & $\begin{array}{c}1.45(0.53) \\
1.00 \\
\end{array}$ & $\begin{array}{c}1.61(0.49) \\
1.00 \\
\end{array}$ & $\begin{array}{c}1.43(0.52) \\
2.00\end{array}$ & 0.003 & $\begin{array}{c}1.63(0.49) \\
2.00 \\
\end{array}$ & $\begin{array}{c}1.41(0.51) \\
1.00\end{array}$ & 0.004 \\
\hline 15 & $\begin{array}{c}1.44(0.57) \\
1.00\end{array}$ & $\begin{array}{c}1.51(0.60) \\
1.00\end{array}$ & $\begin{array}{c}1.43(0.55) \\
2.00\end{array}$ & 0.123 & $\begin{array}{c}1.52(0.56) \\
2.00\end{array}$ & $\begin{array}{c}1.42(0.57) \\
1.00\end{array}$ & 0.386 \\
\hline 29 & $\begin{array}{c}1.37(0.61) \\
1.00\end{array}$ & $\begin{array}{c}1.34(0.63) \\
1.00\end{array}$ & $\begin{array}{c}1.40(0.60) \\
1.00\end{array}$ & 0.423 & $\begin{array}{c}1.42(0.59) \\
1.00\end{array}$ & $\begin{array}{c}1.35(0.63) \\
1.00\end{array}$ & 0.631 \\
\hline 14 & $\begin{array}{c}1.36(0.53) \\
1.00\end{array}$ & $\begin{array}{c}1.41(0.53) \\
1.00\end{array}$ & $\begin{array}{c}1.34(0.52) \\
1.00\end{array}$ & 0.097 & $\begin{array}{c}1.44(0.50) \\
1.00\end{array}$ & $\begin{array}{c}1.32(0.53) \\
1.00\end{array}$ & 0.166 \\
\hline
\end{tabular}

*Numbered according to Figure 1, in descendent order according to mean scores. ${ }^{\star \star}$ Mann-Whitney test

The main finding refers to the professional profile, since more than half of the respondents considered they had totally reached what is proposed in the NCG. Among the general competencies/skills, the item with the highest frequency of total achievement was "Health care", which is the broader indicator, including health prevention, promotion, protection and rehabilitation, both individually and collectively. A similar result was found in a previous study carried out in the South region of Brazil15, where $50.4 \%$ of the students assessed themselves as skilled in this competency.

Among the specific competencies/skills, the item with the highest level of total achievement was related to the ethical and legal principles of the profession, which represent another important aspect in professional training, going beyond technical qualification. Aspects related to the preservation of health and communication with patients, professionals and the community also stood out.

The item with the lowest percentage of achievement was the knowledge and application of scientific research methods, both in patients and in population groups. The competence to interpret the results of these investigations also had a comparatively lower percentage of responses. This is a cause for concern in view of the importance of the evidence-based practice approach as one of the guiding elements of health curricula ${ }^{20}$.

Planning, management and administration also had low frequency of achievement on both general and specific competencies/skills. Similar results were found among students from the Southeast and South Brazilian regions 9,15 . Previous studies have also shown difficulties regarding management and planning among dentists who worked in the public service ${ }^{21}$ and in private clinics ${ }^{22}$.

These findings suggest the need to review how the contents related to these competencies have been addressed by the courses, since they are relevant not only to those who will work in public services, but also in private practice. Thus, contents related to planning, management and administration should be addressed in the disciplines of the public health area, as well as in the others that are part of the curriculum. 
On the other hand, considering that few students felt totally incompetent or lacking competencies for these activities, and that one of the premises of the NCG is the importance of continuing education, these competencies and skills can be further developed post-graduation. Total or partial competence for "Participation in continuing education activities" was reported by almost all the students, confirming this possibility.

Associations found between the students' demographic characteristics and some of their perceived specific competencies and skills are of note. Women's reported ability was higher than mens' ability in those competencies and skills relating teamwork and the social context of the profession. Previous studies have shown that female dental students scored higher on social skills, caring factor, sensitiveness and expression of emotions ${ }^{23,24}$. Men reported higher levels of ability in skills related to decision-making and activities aimed at diagnosis and interventions in diseases, corroborating previous studies in Peru ${ }^{17}$ and Finland ${ }^{18}$. Higher scores among younger participants suggest greater enthusiasm and confidence in relation to the profession compared to older participants. The methodology of the present study, however, does not allow exploring the possible reasons for the differences found.

Strengths in the present study are the sample size and the inclusion of final year students over a five-year period, in contrast to previous studies that were confined to a single class and year. The high response rate may be an indicator of the participants' interest and involvement in the subject. This may have positively influenced the results, contributing to more reliable responses. In addition, the use of a scale-type instrument allowed the measurement of different levels of perception.

One limitation of the present study was the non inclusion of other variables related to the characteristics of the students, besides sex and age, which could broaden the analysis and help to identify the possible factors that influenced the process of acquisition of competencies and skills. It may be worth highlighting here that the data is based on students' self assessment and may not be an accurate measure of their actual competence or ability.

We concluded that most of the final year students considered to have achieved the profile, competencies and skills proposed in the NCG, and that their perceptions were associated with demographic characteristics (age and sex). The study highlighted some aspects of the curriculum that may need to be further developed to meet the needs of the students, particularly in relation to the teaching of planning, administration and management. Future studies addressing the factors that contribute to or hinder the process of competencies and skills acquisition during the course may contribute to the improvement of dental education.

\section{Acknowledgements}

This study was financed in part by the Coordenação de Aperfeiçoamento de Pessoal de Nível Superior - Brasil (CAPES) - Finance Code 001.

\section{References}

1. Murtomaa H. Dental education in Europe. Eur J Dent. 2009 Jan;3(1):1-2. 
2. Haden NK, Hendricson WD, Kassebaum DK, Ranney RR, Weinstein G, Anderson EL, Valachovic RW. Curriculum change in dental education. J Dent Educ. 2010 May;74(5):539-57.

3. Loomer PM, Masalu JR, Mimghaba E, Perry DA. New curriculum in dentistry for Tanzania: competency-based education for patient and population health (2008-2011). J Public Health Policy. 2012 Dec;33(Suppl.1):92-109. doi: 10.1057/jphp.2012.39.

4. Field JC, Cowpe JG, Walmsley AD. The graduating European dentist: a new undergraduate curriculum framework. Eur J Dent Educ. 2017 Dec;21(Suppl. 1):2-10. doi: 10.1111/eje.12307.

5. Cowpe J, Plasschaert A, Harzer W, Vinkka-Puhakka H, Walmsley AD. Profile and competences for the graduating European dentist - update 2009. Eur J Dent Educ 2010 Nov;14(4):193-202. doi: 10.1111/j.1600-0579.2009.00609.x.

6. Chuenjitwongsa S, Oliver RG, Bullock AD. Competence, competency-based education, and undergraduate dental education: a discussion paper. Eur J Dent Educ. 2018 Nov;22(1):1-8. doi: 10.1111/eje.12213.

7. Presidency of the Republic of Brazil. Civil House. [Law No 9.394, of Dec 20, 1996. Law guidelines and bases of national education] [cited 2018 Nov 20]. Available from: http://www.planalto.gov.br/ ccivil_03/leis/19394.htm. Portuguese.

8. Ministry of Education of Brazil. National Council of Education. Higher Education Chamber. [CNE/CES 3 Resolution, of Feb 19, 2002. Institute National Curricular Guidelines for Undergraduate Dentistry Courses] [cited 2018 Nov 20]. Available from:http://portal.mec.gov.br/cne/arquivos/pdf/CES032002. pdf. Portuguese.

9. Arantes ACC, Pinto RS, Ramos TCV, Palmier AC. [Supervised training: what is its contribution to the formation of the bachelor of dental surgery according to the national curricular directives?] Rev APS. $2009 \mathrm{Abr} / J u n ; 12(2): 150-60$. Portuguese.

10. Junges R, Stello RS, Portella FF, Rösing CK, Samuel SMW. Impact of the implantation of a new curriculum in the process of learning in a Faculty of Dentistry in Brazil. Braz Oral Res. 2011 Nov/Dec;25(6):478-84.

11. Gabriel M, Tanaka EE. [Professional dentistry training: students' perception of curricular interaction] Rev ABENO. 2011 Nov/Dec;11(1):19-22. Portuguese.

12. Zilbovicius $C$, Araujo ME, Botazzo C, Frias AC, Junqueira SR, Junqueira CR. A paradigm shift in predoctoral dental curricula in Brazil: Evaluating the process of change. J Dent Educ 2011 Apr;75(4):557-64.

13. Vieira GM, Canto GL. [Evaluation of the curriculum reform of the University of Santa Catarina dentistry course]. Rev ABENO. 2012;12(2):198-206. Portuguese.

14. Toassi RFC, Souza JM, Baumgarten A, Rosing CK. [Curricular evaluation of higher education in dentistry: a discussion about the effects of curriculum changes on health care training in Brazil]. Rev ABENO 2012;12(2):170-7. Portuguese.

15. Fadel $\mathrm{CB}$, Baldani $\mathrm{MH}$. [Perceptions of dentistry course graduates about the national curriculum guidelines]. Trab Educ Saude. 2013 Mai/Aug;11(2):339-54. doi: 10.1590/S1981-77462013000200005. Portuguese.

16. Silveira JLGC, Garcia VL. [Curricular change within dentistry: meanings according to the subjects of the learning]. Interface (Botucatu). 2015;19(52):145-58. Portuguese.

17. Bernabé E, Ludeña MA, Beltrán-Neira RJ. Self-perceived public health competency among recent dental graduates. J Dent Educ. 2006 May;70(5):571-9.

18. Karaharju-Suvanto T, Näpänkangas R, Koivumäki J, Pyörälä E, Vinkka-Puhakka H. Gender differences in self-assessed clinical competence--a survey of young dentists in Finland. Eur J Dent Educ 2014 Feb;18(4):234-40. doi: 10.1111/eje.12092. 
19. Pessoa TRRF, Noro LRA. Pathways for graduation evaluation in Dentistry: logical model building and validation criteria. Cien Saude Colet. 2015;20(7):2277-90. doi: 10.1590/1413-81232015207.13182014

20. Rösing CK, Fernandes MI, Oppermann RV. [Evidence based dentistry: impact on teaching and case report]. Rev Fac Odontol Porto Alegre 2003 Dec;44(Supl):6-8. Portuguese.

21. Costa ICC, Araújo MNT. Definition of abilities profile in public health based on the experience of dentists of public service. Cien Saude Colet. 2011 Dec;16(Supl.1):1181-9.

22. Saliba NA, Moimaz SAS, Prado RL, Garbin CAS. [Perception of dentists about professional training and difficulties of insertion in the labor market]. Rev Odontol UNESP. 2012 Sept/Oct;41(5):297-304.

23. Scarbecz M, Ross JA. Gender Differences in First-Year Dental Students' Motivation to Attend Dental School. J Dent Educ. 2002 Aug;66(8):952-961.

24. Hanna A, Lim BT, Ayers KMS. Emotional Intelligence and Clinical Interview Performance of Dental Students. J Dent Educ. 2009 Sept;73(9):1107-17. 